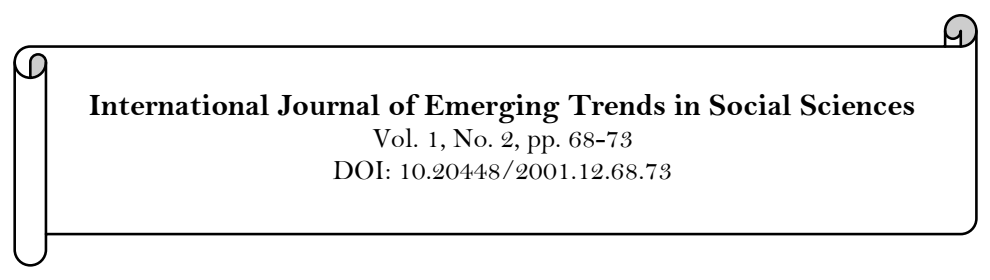

\title{
Use of e-Governance by Administrators of Higher Learning Institutions
}

\section{Muthuselvi ${ }^{1}$ \\ E. Ramganesh ${ }^{2}$}

${ }^{1}$ Ph.D. Research scholar, Department of Educational Technology, Bharathidasan University, Tiruchirappalli, India.

${ }^{2}$ Chair, School of Education, Professor \& Head, Department of Educational Technology, Bharathidasan University, Trichy, India.

\begin{tabular}{|c|c|}
\hline Abstract & \\
\hline $\begin{array}{l}\text { A good higher education system is necessary for inclusive } \\
\text { development of a nation. Also, Electronic Governance (e- } \\
\text { Governance) is becoming the backbone of any country's growing } \\
\text { economy in today's world of internet enabled systems and processes. } \\
\text { The word 'electronic' primarily indicates that the usage of } \\
\text { technology in all matters of governance (Basu, 20O4). e-Governance } \\
\text { is understood as a set of activities involving the effective contribution } \\
\text { of Information and Communication Technology (ICT) for } \\
\text { strengthening administration and management in higher education } \\
\text { system. It can create transparency between the colleges, universities } \\
\text { and students (Suklabaidya \& Sen, 2013). Similarly, the empirical } \\
\text { research states influence of teaching staff towards Institutional } \\
\text { preparedness for e-governance in Indian affiliating Universities is } \\
\text { relatively high (Balasubramanian, Govindaraju, Rao, Uday, \& } \\
\text { Ravindran, 2O12). As well as e-Governance is the fundamental } \\
\text { requirement to make the solution in the field of educational sectors } \\
\text { problems. The present study attempts to ascertain the level of use of } \\
\text { e-Governance by the administrators of the colleges. The survey } \\
\text { design was adapted with the sample of } 110 \text { administrative Personnel } \\
\text { at different level from } 11 \text { arts and science colleges affiliated to } \\
\text { Bharathidasan University. The e-Governance scale with } 30 \text { items } \\
\text { was validated and administered with the sample. Findings reveal that } \\
\text { use of e-Governance by the administrative personnel was found } \\
\text { average besides the extent of use of e-Governance in Government } \\
\text { colleges was low comparing with Self-financing and Aided colleges. } \\
\text { The demographic variables Gender and Locality did not have a } \\
\text { major impact on the use of e-Governance. }\end{array}$ & $\begin{array}{l}\text { Keywords: } \\
\text { E-Governance } \\
\text { Higher education } \\
\text { Information administration. } \\
\text { Licensed: } \\
\text { This work is licensed under a } \\
\text { Creative Commons Attribution } \\
\text { 4.0 License. }\end{array}$ \\
\hline
\end{tabular}

\section{Introduction}

Globalization and technological changes have triggered the transformation in education sector. The higher education sector has seen an enormous growth in recent years and continues to expand. To sustain in the global competitive environment and to withstand the prolific growth of higher education sector a good technology based administration is very much needed (Ramganesh, Kirubakaran, \& Gobi, 2015). UNESCO (2008) has defined "E-governance may be understood as the performance of this governance via the electronic medium in order to facilitate an efficient, speedy and transparent process of disseminating information to the public, and other agencies, and for performing government administration activities." e-Governance is the use of Information and Communication Technology (ICT) for the planning, implementation, and monitoring of government programs, projects, and activities (Kaur \& Mehta, 2014). Snehi (2009); Batta, Sethi, and Kaur (2012); Shah (2013) found the development of MIS would result in efficiency, transparency, accurate and timely information. Mohan, Rao, and Chand (2014); Kumar and Gupta (2015) e-Governance can play a major role to strengthen the technical education system by focusing on Knowledge Management (KM). Oluyemisi (2015) stated institution administrators have a positive perspective towards the use of ICT tools as bringing effectiveness into administration by solving the problem of poor communication. Makewa, Meremo, Role, and Role (2013) in their study both teachers and administrators rated the use of ICT in secondary school administration as important. Teachers and administrators viewed the use of ICT in student administration as 
equally important. According to Hossein (2008) "Information and Communication technology provides several facilities and possibilities for educational administrators to do their tasks". The administrative systems include personnel administration, student administration, resources administration, financial administration and general administration Maki (2008); Shrivastava, Raizada, and Saxena (2014). Based on the literature review the three main functional areas of e-Governance that are of great significance for day-to-day management of higher education institutions was identified by the investigator as presented in the Figure 1 for the items of the survey questioner consisted of components on Student Administration, Staff Administration and General Administration.

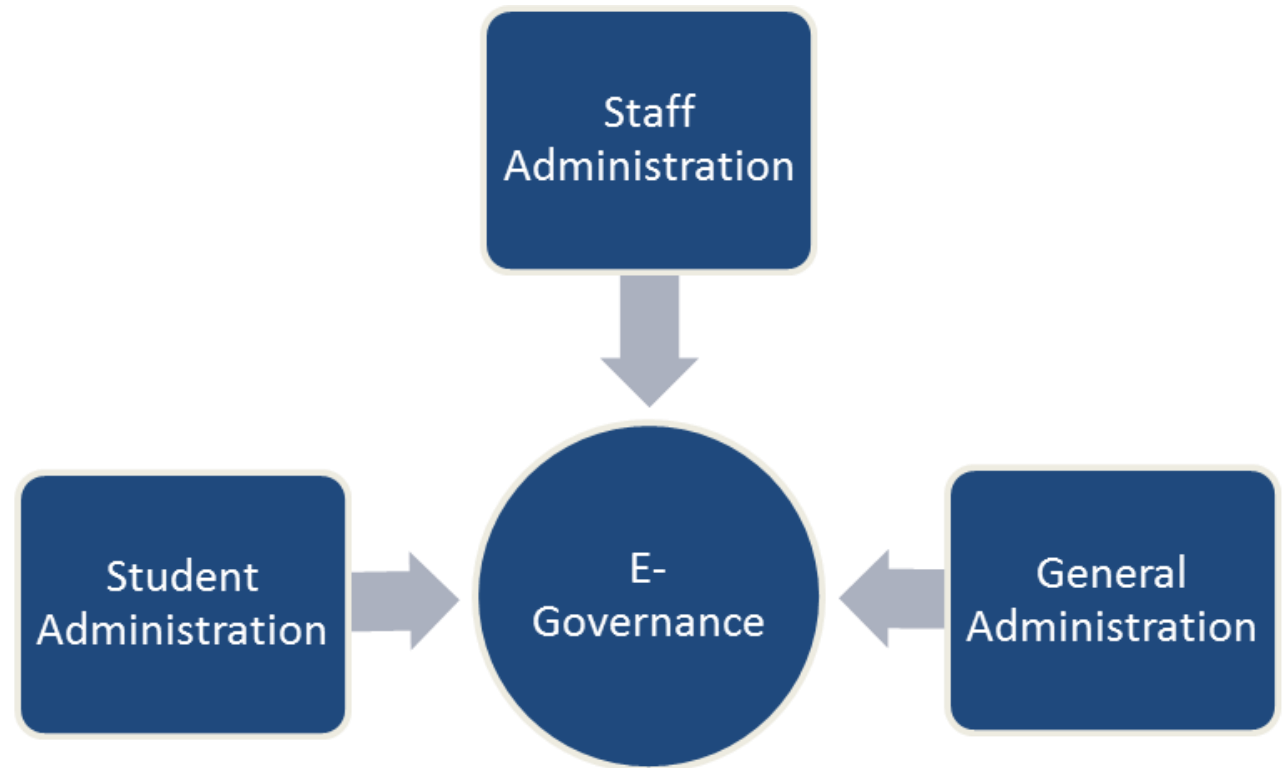

Figure-1. Functional areas of e-Governance.

Source: Krishnaveni and Meenakumari (2010)

Anwar and Mathew (2014);Jaleel (2014); Bhatnagar and Agarwal (2014); Ghavifekr (2013) At first Student administration which involves various activities beginning from the students' admission process to publishing of results and performance analysis. Then Staff Administration which includes recruitment and work allotment of staff in the institution. Also, their attendance, pay slip generation, leave management, and performance appraisal. Finally, General Administration of higher education institutions which incorporates the various day-to-day activities of the entire system. As well as, it helps in processing of voluminous records in a quick, meticulous, and perfect manner.

\subsection{Rationale of the Study}

The higher education faces tough challenges in the recent times due to the growing international demands. Seddiky (2015) stated that the present education system could not work effectively to meet the ever evolving demands in today's competitive environment. In deed the whole education system is not updated and effective to face the challenges of electronic governance. The Modern world is now around with the idea of eGovernance and all countries want to go ahead with this concept to ensure development in global context (Kumars, 2012). Use of e-Governance in educational management will benefit for analyzing the data accurately quick, decision making, provides the power to the administrators for efficient management of education and institution. e-Governance helps in improving transparency, dissemination, accountability and public services in all the aspects of education (Kapoor \& Kelkar, 2013; Shrivastava et al., 2014). The purpose of implementing e-governance in any educational system will enable effective monitoring of academic standards and broaden innovations. In addition, it will help for the betterment of the higher education in the country and increase the number of employable students. Selwood (2004) has analysed the primary teachers' actual use of ICT for administration and management. As a result, the levels of e-governance use are quite low. Ramganesh et al. (2015) in their study states that $\mathrm{m}$-Governance is not a replacement for e-Governance, rather it complements e-governance. m-Governance enables the students \& administrators to access easily, to use new class of quality of services and to provide multi-channel service delivery system. Such a inclusive and integrated system can also enable authorities to analyze the performance of one of the best performing institutes and compare it with other colleges to identify the gaps. Also, the system can obtain feedback from students to modify the course curriculum (Alam, 2016). Indian government has offered several ICT facilities for the past few decades. Even though they are investing more money on ICT infrastructure, the institutions still are not attaining the expectations. Most of the Higher Education Institutions do not leverage e-Governance up to the mark to address the demands of their stakeholders. The need of the hour is to understand the gaps and failures 
in the implementation of e-Governance in higher education. In that way, the present study makes its attempt to assess the extent of use of e-Governance by the administrative personnel of affiliated Arts and Science colleges in Bharathidasan University.

\subsection{Research Questions}

1. Does e-Governance contribute for Information administration of Arts and Science colleges affiliated to Bharathidasan University?

2. Do Gender, Type of Institution and Locality play a role in determining the use of e-Governance?

\section{Methodology}

The investigator adopted descriptive method with a survey technique. Kothari (2008) states that the descriptive studies may include present facts, existing conditions concerning the nature of persons, a number of class of events and may entail procedures of enumeration, induction analysis, classification, details and measurement. Simple random sampling technique was used to collect the data. Data was collected from administrative personnel of 11 affiliated Arts and Science colleges in Bharathidasan university. The collected data were analyzed for further understanding. SPSS Package was used to analyse the data. Percentage analysis and Chi-square test were used.

\section{Tool}

The 'e-Governance scale' was developed by the investigators. The questionnaire consists of 30 items representing all the three dimensions such as General administration, Staff administration and Student administration. The responses for the questionnaire received from administrative personnel consisted of a three point Likert type scale with three options such as Always, Sometimes and Not at all.

For ascertaining face validity and content validity, the items that contribute towards all the three functional areas were carefully identified through extensive literature review and discussions with educational practitioners and experts. Reliability test was done using SPSS software. Cronbach's Alpha test was adopted to measure the reliability of the tool because, it is an important concept in the evaluation of assessments and questionnaires. Alpha provides a measure of the internal consistency of a test or scale (Tavakol \& Dennick, 2011). The reliability coefficient for the tool is 0.871 .

\section{Results and Discussion}

\subsection{Descriptive Statistics}

Descriptive analysis summarizes the data meaningfully. It is used to measure the central tendency and the variability of the research data. Percentage analysis is normally used to compare one variable with other variables. Here this was done to identify the extent of usage of technology for Functional areas of eGovernance such as Student Administration, Staff Administration, General Administration and Overall Administration.

Table-1. Descriptive analysis the Use of e-Governance.

\begin{tabular}{l|l|l|l|l}
\hline $\begin{array}{l}\text { Functional areas of } \\
\text { e-Governance }\end{array}$ & $\mathbf{N}$ & $\begin{array}{l}\text { No of } \\
\text { items }\end{array}$ & Mean & Use of e-Governance(\%) \\
\hline Student admin & 110 & 10 & 1.406 & 80.21 \\
\hline Staff admin & 110 & 10 & 1.387 & 79.57 \\
\hline General admin & 110 & 10 & 1.159 & 71.96 \\
\hline Overall admin & 110 & 30 & 1.317 & 77.25 \\
\hline
\end{tabular}




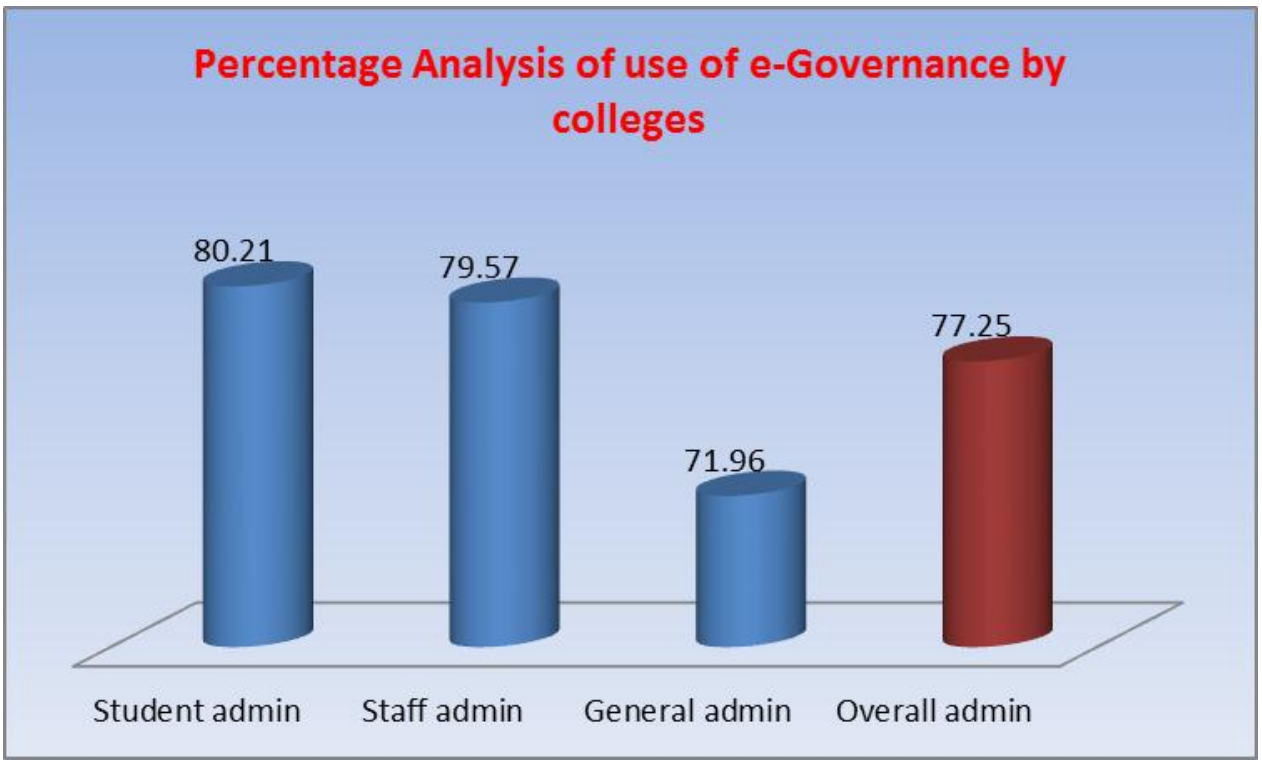

Figure-2. Use of e-Governance by Colleges.

Figure 2 indicates that the use of e-Governance. It was found that as many as $77.25 \%$ of the respondents use e-Governance. It was found from the analysis that $80.21 \%$ of the respondents leverage e-Governance for Student administration, $79.57 \%$ for Staff administration and $71.96 \%$ for General administration.

The above obtained result supports the previous findings of study conducted by Krishnaveni and Meenakumari (2010). This study confirms e-Governance is mainly used in the areas of student administration and staff administration. The extent of usage for general administrative activities was comparatively less. Having done the descriptive statistics the investigators attempted the Chi-Square test to find out the influence of demographic factors in the usage of e-Governance. The Chi-Square statistic provides a statistical test for ascertaining whether the association exist between disease and exposure (Marie, 2008)..

Table-2. Differential analysis of the use of e-Governance.

\begin{tabular}{|c|c|c|c|c|c|c|c|c|}
\hline \multicolumn{9}{|c|}{ Use of e-Governance } \\
\hline \multicolumn{2}{|c|}{ variable } & $\mathbf{N}$ & Mean & S.D & df & $\begin{array}{l}\text { Chi- } \\
\text { Square }\end{array}$ & $\begin{array}{l}P \\
\text { value }\end{array}$ & $\begin{array}{l}\text { Significant at } \\
0.05 \text { level }\end{array}$ \\
\hline \multirow{2}{*}{ Gender } & Male & 53 & 64.43 & 11.96 & \multirow[b]{2}{*}{23} & \multirow[b]{2}{*}{26.520} & \multirow[b]{2}{*}{0.277} & \multirow{2}{*}{ Not significant } \\
\hline & Female & 57 & 67.65 & 11.21 & & & & \\
\hline \multirow{3}{*}{$\begin{array}{l}\text { Type of } \\
\text { Institution }\end{array}$} & Government & 30 & 58.3667 & 3.35 & \multirow{3}{*}{46} & \multirow{3}{*}{1.276} & \multirow{3}{*}{0.000} & \multirow{3}{*}{ Significant } \\
\hline & Aided & 30 & 73.7000 & 2.63 & & & & \\
\hline & Self & 50 & 73.7200 & 2.75 & & & & \\
\hline \multirow{2}{*}{ Locality } & Rural & 50 & 67.2400 & 7.76 & \multirow[b]{2}{*}{23} & \multirow[b]{2}{*}{25.431} & \multirow[b]{2}{*}{0.328} & \multirow{2}{*}{ Not significant } \\
\hline & Urban & 60 & 71.4333 & 6.64 & & & & \\
\hline
\end{tabular}

$\mathrm{SD}=$ Standard Deviation.

It can be seen from the Table 2 that there is no significant gender difference in administrative staffs of Arts and Science colleges $(p=0.277$, Chi-Square $=26.520, \mathrm{df}=23)$. The $\mathrm{p}$ value 0.277 for the variable gender is not found significant at 0.05 level. Bhatnagar and Agarwal (2014) was of the opinion that the gender did not have a influence in the use of e-Governance.

From the above Table 2 the Chi-square test analysis indicates a significant difference in administrative staffs of Government, Aided and Self- financing colleges usage of e-Governance at 0.05 level of significance. $(\mathrm{p}=0.328$, Chi-Square $=25.431 \mathrm{df}=23)$. Hence, private colleges are better use of e-Governance than that of the Government colleges.

Also, the above Table 2 indicates that there is no significant difference in the locality of the institution $(\mathrm{p}=0.119$, Chi-Square $=1.570, \mathrm{df}=105)$. The $\mathrm{p}$ value 0.119 is greater at 0.05 level. Therefore, locale did not have its influence in the usage of e-Governance. However the most of the demographic factors not have any significant difference in the functional areas of Information administration. This finding is supported by the previous research conducted by Jaleel (2014). 


\subsection{Recommendations for Policy Making}

- The extent of use of e-Governance in Government colleges was found low because of inadequate infrastructure. So, there is an immediate need to revitalize the Government colleges. By providing sufficient financial resources for upgrading e-Governance and taking some schemes, policies and strategies for adapting e-Governance to ensure good governance.

- The essential requirement in e-governance is training programme for policy makers and recruit an Information Technology (IT) specialist for every Institution. The constructive legal framework may be established for applying e-Governance properly in education sector.

\section{Conclusion and Discussion}

E-Governance plays a vital role in supporting powerful, efficient management and administration in education sector. It is specified that technology can be used right from student administration to various resource administration in an education institution (Maki, 2008). Based on the various literature, it is felt that the use of ICTs in admission process, maintenance of students' personal and other academic records, submission of class assignments and projects, monitoring and evaluation, and communications with the stakeholders is unavoidable for sustainable development of the educational establishments. This study has identified a comprehensive set of functional areas of e-Governance. It was found that more than $70 \%$ use of eGovernance for information based administration in higher education institutions. As the leverage of eGovernance by the Government colleges was found low, sufficient infrastructural facilities may be upgraded for the optimum use of e-Governance and the administrators and stakeholders may be motivated use of eGovernance for enjoying the transparency. Also, this study reveals that most of the demographic factors do not have major impact on Information administration in higher education institutions. The modest efforts taken by the study could serve as a base for education planers to deploy Technology based administration in higher education Institutions, in future towards the achievement of transparency and satisfaction in governance.

\section{References}

Alam, M. (2016). Use of ICT in higher education. The International Journal of Indian Psychology, 3(4), 162-171.

Anwar, S., \& Mathew, D. S. K. (2014). The contribution of ICT in higher education: A multifaceted approach. IOSR Journal of Electronics and Communication Engineering, 9(1), 60-63. Available at: 10.9790/2834-09156063.

Balasubramanian, K., Govindaraju, M., Rao, K. P., Uday, C., \& Ravindran, C. (2012). Friction stir processed rare earth containing magnesium alloy for high temperature application. Paper presented at the Materials Science Forum.

Basu, S. (2004). E-government and developing countries: An overview. International Review of Law, Computers \& Technology, 18(1), 109-132. Available at: 10.1080/13600860410001674779.

Batta, M., Sethi, A., \& Kaur, R. (2012). E - governance in E - administration. International Journal of Computing \& Business Research

Bhatnagar, M., \& Agarwal, B. (2014). Impact of information and communication technology in higher education institutions. International Journal of Advance Research in Science and Engineering, 3(1), 216-222.

Ghavifekr, S. (2013). ICT application for administration and management (pp. 1344-1351). A conceptual review: Elsevier Ltd.

Hossein, Z. (2008). Administration of faculties by information and communication technology and its obstacles. International Journal of Education and Information Technologies, 2(1), 24-30.

Jaleel, A. (2014). Administration of information in higher education-role of ICT. International Journal of Engineering Sciences छ Research Technology, 2(2), 2277-9655.

Kapoor, R., \& Kelkar, N. (2013). E - governance: Higher education in rural area. Paper presented at the Proceedings of National Conference on New Horizons in IT - NCNHIT.

Kaur, C., \& Mehta, P. (2014). Role of E-Governance to strengthen higher education system in India. International Journal of Scientific and Innovative Research, 2(1), 270-276.

Kothari, C. R. (2008). Research methodology, methods and techniques (2nd ed., pp. 109-110). New Delhi: New Age InterNational (P) Limited.

Krishnaveni, R., \& Meenakumari, J. (2010). Usage of ICT for information administration in higher education institutions a study. International Journal of Environmental Science and Development, 1(3), 282-286.

Kumar, P., \& Gupta, R. K. (2015). IJISET - International Journal of Innovative Science, Engineering \& Technology, 2(8).

Kumars, A. (2012). E-governance in education sector. Gian Jyoti E-Journal, 1(2).

Makewa, L., Meremo, J., Role, E., \& Role, J. (2013). ICT in secondary school administration in rural southern Kenya: An educator's eye on its importance and use. International Journal of Education and Development using Information and Communication Technology, 9(2), 48-63.

Maki, C. (2008). Information and communication technology for administration and management for secondary schools in cyprus. Journal of Online Learning and Teaching, 4(3), 18-20.

Marie, W. D. (2008). Use of the chi-square statistic.

Mohan, C., Rao, S., \& Chand. (2014). E- governance in education system - knowledge management based economy. Abhinav National Monthly Refereed Journal of Research in Commerce \& Management(5).

Oluyemisi, A. (2015). ICT and effective school management: Administrators' perspective. Proceedings of the World Congress on Engineering: 
Ramganesh, E., Kirubakaran, E., \& Gobi, R. (2015). A roadmap for a higher learning institution based m-governance framework in the grey revolution. International Journal of Advanced Research in Computer Science and Software Engineering, 5(8), 152-155.

Seddiky, A. (2015). Application of E-governance in education sector to enhance the quality of education and human resource development in Bangladesh. European Scientific Journal, 11(4), 386-404.

Selwood, I. (2004). Primary school teachers' use of ICT for administration and management. Retrieved from www.springer.com/cda/content/document/cda.../9780387240442-c2.pdf?SGWID.

Shah, M. (2013). Impact of management information systems (MIS) on school administration: What the literature says. Elsevier Ltd, 2799 - 2804. Available at: 10.1016/j.sbspro.2014.01.659.

Shrivastava, R. K., Raizada, A. K., \& Saxena, N. (2014). Role of E - governance to strengthen higher education system in India. IOSR Journal of Research \& Method in Education, 4(2), 57 - 62.

Snehi, N. (2009). ICT in Indian universities and colleges: Opportunities and challenges. Management $\Xi^{2}$ Change, 13(2), 231244.

Suklabaidya, S., \& Sen, A. M. (2013). Challenges and prospects of E - governance in education. International Journal of Emerging Trends \& Technology in Computer Science, 2(3), 258-262.

Tavakol, M., \& Dennick, R. (2011). Making sense of Cronbach's alpha. International Journal of Medical Education, 2, 53-55.

UNESCO. (2008). Digital public administration and E-government in developing nations: policy ... edited by Halpin, Edward Francis. 